\title{
Synthesis and Anticancer Activity of (E)-2'-hydroxy-2-bromo-4,5-dimethoxychalcone Against Breast Cancer (MCF-7) Cell Line
}

\author{
Retno Aliyatul Fikroh', Sabirin Matsjeh², Chairil Anwar² \\ 'Department of Chemistry Education, Faculty of Science and Technology, UIN Sunan Kalijaga, Yogyakarta \\ ${ }^{2}$ Department of Chemistry, Faculty of Mathematics and Natural Science, Universitas Gadjah Mada, \\ Yogyakarta
}

*Corresponding author email: aliyafikroh1992@gmail.com

Received August 02, 2019; Accepted February 23, 2020; Available online March 15, 2020

\begin{abstract}
Breast cancer is one of cancer causes of death in woman. Chemotherapy is one cancer treatment give toxic effects on normal cells. Alternative of cancer treatment by using flavonoid derivative have potent anticancer to reduce side effects of cancer. Chalcone is family of flavonoid that have biological activity. Chalcone derivatives have the potent as anticancer agent. Chalcone with the presence halogen, metoxy group in ring B is known to inhibit cancer cells. The aims of this research were to synthesize chalcone derivative with bromo, methoxy, and hydroxy groups in chalcone ring and to determine the anticancer activity of chalcone derivative. The chalcone derivative was synthesized from 2 hydroxyacetophenone with 2-bromo-4,5-dimethoxybenzaldehyde by Claisen-Schmidt reaction. In vitro cytotoxicity against breast cancer cell was tested by MTT assay method. The compound of (E)-2'-hydroxy-2-bromo-4,5-dimethoxychalcone was yield in $78 \%$ as yellow solid. The $\mathrm{IC}_{50}$ of $(E)$-2'-hydroxy-2-bromo-4,5-dimethoxychalcone was $42.19 \mu \mathrm{g} / \mathrm{mL}$ as a moderate activity to inhibiting breast cancer cell line. Cytotoxity of docorubicin againts breast cancer cell line more active than (E)-2'-hydroxy-2-bromo-4,5-dimethoxychalcone with $\mathrm{IC}_{50} 10.61 \mu \mathrm{g} / \mathrm{mL}$. Doxorubicin as drug standar had better anticancer activity than (E)-2'-hydroxy-2-bromo-4,5-dimethoxychalcone. Based on the $\mathrm{IC}_{50}$ value, (E)-2'-hydroxy-2-bromo4,5-dimethoxychalcone has a moderate activity towards breast cancer cell lines. Thus, this compound can be recommended as candidate for anticancer againts breast cancer cell lines.
\end{abstract}

Keyword : anticancer; chalcone derivative; breast cancer

\section{INTRODUCTION}

Cancer is a diseases involving uncontrolled growth of abnormal cell in body. Cancer became the second leading cause of death after cardiovascular disease (Sashidhara, Kumar, Kumar, Sarkar, \& Sinha, 2010). Based on the World Health Organization (WHO) estimation, in 2030 the deaths caused by cancer will increase by $44 \%$ with respect to 2008. Breast cancer is the most common invasive cancer in female worldwide (Mellado-Garcia, Reyna, Weinstein-Oppenheimer, Cuellar, \& Aguilar, 2018). It accounts for $16 \%$ of all female cancers and $22.9 \%$ of invasive cancers in woman, $18.2 \%$ of all cancer deaths worldwide including both in males and females are from breast cancer (Rajak et al., 2010). Breast cancer became the first ranked among other cancers disease cause of death from cancer in woman from hospital data in Indonesia. In 2013, breast cancer is type of cancer with most occured in Indonesia with 61,682 cases (Kementerian Kesehatan, 2015).

There are many diagnostic methods and therapeutic approaches for cancer including surgery, radiation, chemotherapy, hormone therapy and biologycal therapy (Kameshwaran, Suresh, Arunachalam, Kanthlal, \& Mohanrai, 2012). Nowdays, chemotherapeutic agents is one of the notable healing approaches for several cancer types, e.g breast (Smith, Heutcheon, \& Heys, 2000). The problem of chemotherapeutical is able to kill cancer cell but also kill normal cells around (Ketabforoosh, Kheirollahi, Safavi, \& Esmati, 2014). Ranjit et al. (2013) reported that chemotherapeutic agents can be used as an alternative cancer treatment but some chemotherapeutic agents give negative effects such as depression and alopecia. Therefore, novel anticancer agents must be developed in the medical chemistry.

Natural products have been used to develop new compounds with potential application for several pharmacological treatments (Yu, Shen, Song, \& Xie, 2018). Polyphenolic compounds that have been reported to posses anticancer e.g flavonoids and their derivative compounds (Agrawal, 2011). Chalcone, the precursors of flavonoids, are widely present in fruits, vegetables, and are present in plant species (Zaini et al., 2019). Chemically, they consist of open-chain flavonoids in which the two aromatic 
rings are joined by a three-carbon $\alpha \beta$-unsaturated carbonyl system (Syam, Abdelwahab, Al-mamary, \& Mohan, 2012). Chalcone have been reported as several pharmacological activity including antiinflammatory (Hsieh, Lee, Wang, Wang, \& Lin, 1998), antifungal (Sivakumar, Muthu Kumar, \& Doble, 2009), antimalaria (Syahri, Yuanita, Nurohmah, Armunanto, \& Purwono, 2017), and anticancer (Bonakdar et al., 2017). Substituents on chalcones have an important role in improving activity og anticancer againts. According to Rao, Fang, \& Tzeng (2004) reported that chalcone with methoxy groups on the aromatic ring has potential as an anti-proliferation in tumor cells without giving any toxic effects on normal cells. Sofiana, Balatif, \& Zamri (2014) states that chalcone with methoxy groups have a greater toxic properties due to the $\alpha \beta$ unsaturated bond and mesomeri positive effects from methoxy substituted.

Ketabforoosh et al. (2014) have tested the activity chalcone without substituent between 2-bromo hydroxyacetophenone and veratraldehyde with $I_{50}$ value of $6.1 \mu \mathrm{M}(1.73 \mathrm{mg} / \mathrm{mL})$ against breast cancer cells MCF-7. The study also synthesized chalcone between 2-hydroxyacetophenone and veratraldehyde with bromo substituted have $\mathrm{IC}_{50}$ value of $1 \mu \mathrm{M}(0.36$ $\mathrm{mg} / \mathrm{mL}$ ), it is lower than compound without the bromo substituent that is equal to $1 \mu M(0.36$ $\mathrm{mg} / \mathrm{mL}$ ). This shows that the halogen substituent such as bromo also have activity in inhibiting breast cancer. Chalcone derivatives with halogen substituent such as bromo very useful to modulate the electron and steric characteristics of the drug as well as affecting the balance of the hydrophilic hydrophobic molecules.

Syam et al. (2012) have synthesized chalcone with halogen substituent such as cloro at ring $B$ with $I_{50}$ value of $7.991 \mu \mathrm{g} / \mathrm{mL}$ and methoxy substituen with $I_{50} 11.625 \mu \mathrm{g} / \mathrm{mL}$. In this research showed that chalcone with halogen subtituent in ring $B$ increased the ROS level eventually leading to apoptosis in MCF-7 cells through intrinsic as well as extrinsic pathways. According to the available data, we synthesized a novel chalcone derivative by presence halogen and methoxy substituents at ring $B$ of chalcone to find a new anticancer agent. The synthesis of chalcone in this research used simple steps with produced in more than $50 \%$ yield. The cytotoxicity was determined by MTT assay toward breast cancer (MCF-7) cell lines.

\section{EXPERIMENTAL SECTION Materials}

The material with pro analysis grade were purchased from Merck, i.e., 2-hydroxyacetophenone, 3,4-dimethoxybenzaldehyde, sodium hydroxide, ethyl ecetate, ethanol, methanol, $n$-hexane, glacial acetic acid, hydrocloric acid, hydrobromic acid, while sodium sulfate anhydrous and potassium bromate were from Sigma-Aldrich. All reactions were monitored with Thin Layer Chromatography plat of aluminium F254 from Merck were obtained with silica gel $60(20 \times 20 \mathrm{~cm})$. Purification was performed by column chromatography from Merck with silica gel 60 .

The material for in vitro test were breast cancer cell line (MCF-7), doxorubicin, fetal bovine serum $10 \%(w / v)$ from Sigma-Aldrich, Medium Dulbecco's Modified Eagle's Medium (DMEM) from SigmaAldrich, dimethyl sulfoxide, Sodium Dedocyl Sulfate (SDS) 10\%, Phospate Buffer Solution (PBS), solution of MTT (3-(4,5-dimethythiazol-2-yl)-2,5diphenyltetrazolium-bromide and hydroclorid acid $0.1 \mathrm{~N}$.

\section{Instrumentation}

The instrumentation in this research were used several instrument such as infra red spectra was recorded with Shimadzu Prestige-21 FTIR Spectrometer using $\mathrm{KBr}$ pellets, Mass Spectra was recorded with Shimadzu GC-MS QP2010S, 'H and ${ }^{13} \mathrm{C}-\mathrm{NMR}$ were JEOL JNM ECA500 (500 Mhz) using internal standard TMS with chloroform and dimethyl sulfoxide as solvents.

The cytotoxic test were performed using $\mathrm{CO}_{2}$ incubator (NAPCO models 6200, Heraeus), microwell plate 96 (Iwaki), yellow and blue micropipette tips, sterile tubes, autoclave, micropipette 2-20 mL (Nichipet H32014262), 20$100 \mathrm{~mL}$ and 200-1000 mL (Gilson X57732D), Laminar Air Flow (LABCONCO), hemocytometer (Neubaver), microscope inverted (Olympus CKX41$1 \times 2 S L)$.

\section{Synthesis of 2-Bromo-4,5-dimethoxybenzaldehyde}

Potassium bromate $(0.8 \mathrm{~g}, 4.8 \mathrm{mmol}), 3,4$ dimethoxybenzaldehyde $(2 \mathrm{~g}, 12 \mathrm{mmol})$ and glacial acetic acid $(20 \mathrm{~mL})$ was place in $125 \mathrm{~mL}$ threenecked flask with magnetic stirrer. The mixture was stirred rapidly and $4 \mathrm{~mL}$ hydrobromic acid $47 \%$ was dropped into it. After each addition, a red brown mixture was appeared. A mixture was stirred for 60 minutes in room temperature. Then $50 \mathrm{~mL}$ cool water was added and stirred for 10 minutes. Sodium thiosulfate anhydrous was added drop wise into a mixture until a gray precipitate appeared, filtered, and washed with water and crystallized from $50 \%$ ethanol. The solid that precipitated was measured by TLC monitoring, spectroscopy analysis with 'HNMR.

\section{2-Bromo-4,5-dimethoxybenzaldehyde}

Molecular formula $\mathrm{C}_{9} \mathrm{H}_{9} \mathrm{BrO}_{3}, \mathrm{~m} / \mathrm{z} 244[\mathrm{M}+\mathrm{H}]^{+}$, yield $82 \%$, m.p. $145^{\circ} \mathrm{C}, \mathrm{FT}-\mathrm{IR}\left(\mathrm{KBr}\right.$ disc): $2777 \mathrm{~cm}^{-}$ '(aldehyde $\mathrm{C}-\mathrm{H}) ; \quad 1666 \mathrm{~cm}^{-1}(\mathrm{C}=\mathrm{O}) ; \quad 2777 \mathrm{~cm}^{-}$ '(aldehyde C-H); 1589 dan $1442 \mathrm{~cm}^{-1}$ (aromatic $\mathrm{C}=\mathrm{C}), 655 \mathrm{~cm}^{-1}(\mathrm{C}-\mathrm{Br})$; ${ }^{1} \mathrm{H}-\mathrm{NMR}\left(\mathrm{CDCl}_{3}, 500 \mathrm{MHz}\right)$ : $3.92\left(\mathrm{~s}, 3 \mathrm{H}, \mathrm{OCH}_{3}\right) ; 3.96\left(\mathrm{~s}, 3 \mathrm{H}, \mathrm{OCH}_{3}\right) ; 7.05$ (s, $1 \mathrm{H}) ; 7.41(\mathrm{~s}, 1 \mathrm{H}) ; 10.18(\mathrm{~s}, 1 \mathrm{H}, \mathrm{CHO})$. 


\section{Synthesis}

dimethoxychalcone

(E)-2'-Hydroxy-2-bromo-4,5-

Into $100 \mathrm{~mL}$ three-necked flask, $1.22 \mathrm{~g} \mathrm{(5} \mathrm{mmol)}$ of 6-bromoveratraldehyde and $20 \mathrm{~mL}$ methanol were added. Then added $0.68 \mathrm{~g}(5 \mathrm{mmol})$ of 2 hydroxyacetophenone which has reacted with $12 \mathrm{~mL}$ of $40 \% \mathrm{NaOH}$ for \pm 30 minutes to a solution of 6 bromoveratraldehida. The reaction mixture was heated for $24 \mathrm{~h}$ at $68{ }^{\circ} \mathrm{C}$. The mixture was poured into ice and acidified by $10 \% \mathrm{HCl}$ until yellow precipitate formed. The precipitate was crystallized from ethanol to give pure compounds.

\section{Chalcone}

dimethoxychalcone

(E)-2'-hydroxy-2-bromo-4,5-

Molecular formula $\mathrm{C}_{17} \mathrm{H}_{15} \mathrm{O}_{4} \mathrm{Br}, \mathrm{m} / \mathrm{z} 364[\mathrm{M}+\mathrm{H}]^{+}$, yield $78 \%$, m.p. $169-170^{\circ} \mathrm{C}$, FT- $\mathrm{IR}(\mathrm{KBr}$ disc): 3441 $\mathrm{cm}^{-1}(\mathrm{OH}) ; 3086$ (alkene C-H); 1635(C=O); 1504 and 1573 (aromatic $\mathrm{C}=\mathrm{C}$ ); 1026 (C-O-C); 972 (alkene $\mathrm{C}-\mathrm{H}$ olefin trans); 663(C-Br); ${ }^{\mathrm{H}} \mathrm{H}-\mathrm{NMR}$ $(\mathrm{CDCl} 3,500 \mathrm{MHz}): 3.93\left(\mathrm{~s}, 3 \mathrm{H}, \mathrm{OCH}_{3}\right) ; 3.97(\mathrm{~s}, 3 \mathrm{H}$, $\left.\mathrm{OCH}_{3}\right) ; 6.95(\mathrm{dd}, \mathrm{J}=7.75$ and $\mathrm{J}=7.8 \mathrm{~Hz}, 1 \mathrm{H}) ; 7.03$ $(\mathrm{d}, \mathrm{J}=8.4 \mathrm{~Hz}, 1 \mathrm{H}) ; 7.10(\mathrm{~s}, 1 \mathrm{H}) ; 7.20(\mathrm{~s}, 1 \mathrm{H}) ; 7.45$ $\left(d, \mathrm{JH}_{\alpha}=15.55 \mathrm{~Hz}, 1 \mathrm{H}, \mathrm{H}_{\alpha}\right) ; 7.49(\mathrm{dd}, \mathrm{J}=7.8$ and $J=7.8 \mathrm{~Hz}, 1 \mathrm{H}) ; 7.91(\mathrm{~d}, J=7.8 \mathrm{~Hz}, 1 \mathrm{H}) ; 8.21(\mathrm{~d}$, $\left.\mathrm{JH}_{\beta}=15.55 \mathrm{~Hz}, 1 \mathrm{H}, \mathrm{H}_{\beta}\right) ; 12.81(\mathrm{~s}, 1 \mathrm{H}, \mathrm{OH}) .{ }^{13} \mathrm{C}-$ NMR $\left(\mathrm{CDCl}_{3}, 125 \mathrm{MHz}\right): 56.38 ; 56.44 ; 109.67$; 115.97 ; 117.85 ; 118.79 ; 118.95; 120.08 ; 120.52; $126.65 ; 129.76 ; 136.52 ; 143.96$; 148.83; 152.00; $163.71 ; 193.51$.

In Vitro Test of (E)-2'-hydroxy-2-bromo-4,5dimethoxychalcone against breast cancer (MCF-7) Cell Line

MCF-7 cancer cells were cultured in 96-well plate at a density of $10^{6}$ cells per well and incubated in incubator $\left(37^{\circ} \mathrm{C}\right.$ in a $\left.5 \% \mathrm{CO}_{2}\right)$ for $24 \mathrm{~h}$. Compound solution and doxorubicin with varying concentration were put in well plate that had been incubated. After $24 \mathrm{~h}$ incubation, the culture medium was removed, washed with PBS and treated with $100 \mu \mathrm{L}$ of MTT. Plate was incubated for $4 \mathrm{~h}$. Next, 10\% sodium dodecyl sulfate in $0.1 \mathrm{~N} \mathrm{HCl}$ was added to dissolve the purple formazan. After an overnight incubation at room temperature, the absorbance was measured at $595 \mathrm{~nm}$ by ELISA reader. Percent viability was calculated as

$$
\frac{\text { (absorbance of sample }- \text { absorbance media controls) }}{\text { (absorbance of cell controls }- \text { absorbance media controls) }} \times 100
$$

\section{RESULTS AND DISCUSSION}

Synthesis of 2-Bromo-4,5-dimethoxybenzaldehyde

The compound of 2-bromo-4,5dimethoxybenzaldehyde has been synthesized from potassium bromate and 3,4-dimethoxybenzaldehyde with glacial acetat acid. The IR spectra showed dissapearing peak $1674 \mathrm{~cm}^{-1}$ (aldehyde) and new peak appeared at $1666 \mathrm{~cm}^{-1}$ as conjugated carbonyl vibration. The product also showed peak $655 \mathrm{~cm}^{-1}$ as stretch vibration of $\mathrm{C}-\mathrm{Br}$. It is indicated that 2-bromo4,5-dimethoxybenzaldehyde has been synthesized. The mass spectrum of 2-bromo-4,5dimethoxybenzaldehyde at $\mathrm{m} / \mathrm{z} 244$ and 246 for $\mathrm{M}^{+}$.

Based on 'HNMR analysis, the product has 5 different types of protons according to the target compound. The absorption protons of methoxy were clarified with the appearing of a singlet peaks at 3.92 and $3.96 \mathrm{ppm}$. The characteristic of aromatic compounds were appearing of a singlet peaks at 7.05 and $7.41 \mathrm{ppm}$. The absorption of aldehyde group showed with the appearing of a singlet peaks at $10.18 \mathrm{ppm}$. The spectra ${ }^{~} \mathrm{HNMR}$ was presented in Figure 1 .

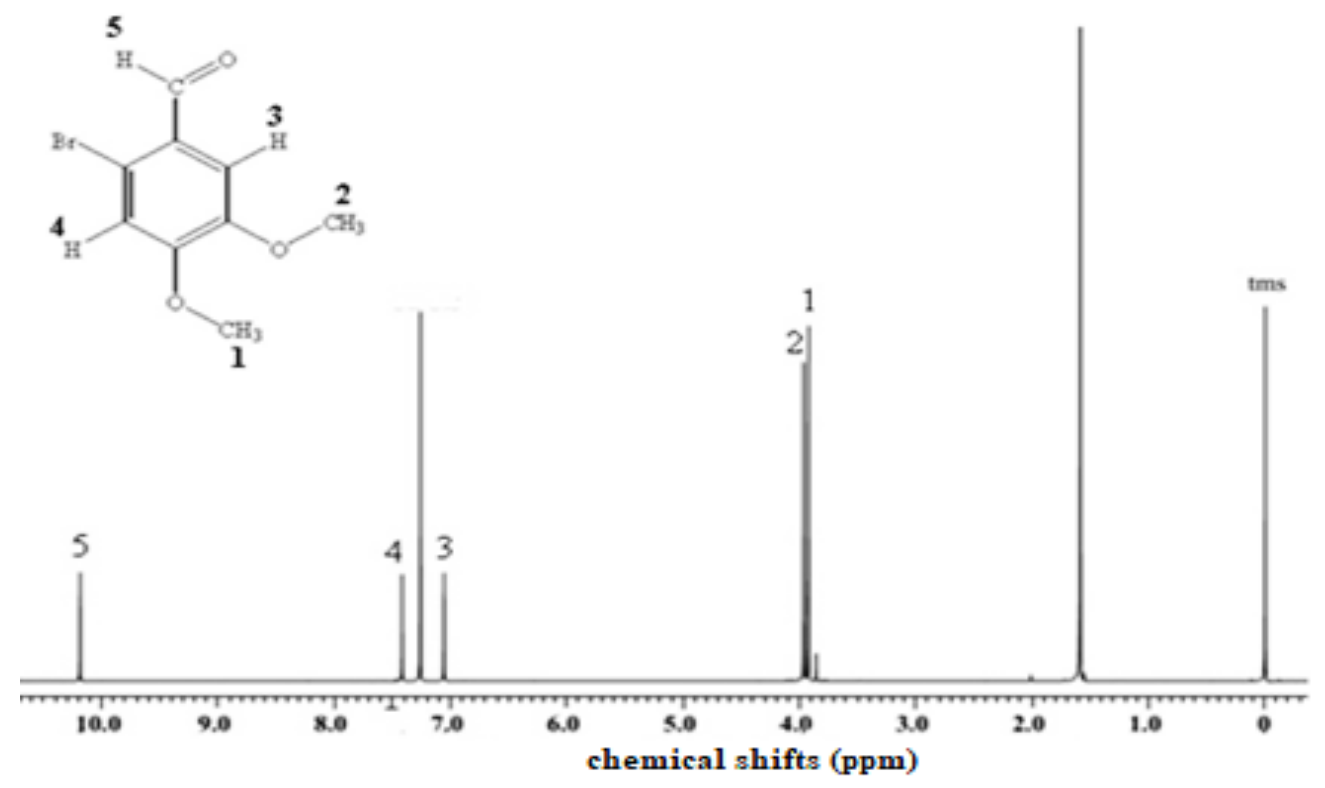

Figure 1. The 'HNMR spectra of 2-bromo-4,5-dimethoxybenzaldehyde with $\mathrm{CDCl}_{3}$ as solvents 
<smiles>COc1ccc(C=O)cc1OC</smiles><smiles>COc1cc(Br)c(C=O)cc1OC</smiles>

Figure 2. Synthesis 2-bromo-4,5-dimethoxybenzaldehyde

Based on IR and 'HNMR spectra, it was showed that bromination 3,4-dimethoxybenzaldehyde using potassium bromate with acetat glacial acid has produced 2-bromo-4,5-dimethoxybenzaldehyde compound. The product was a white solid in $82 \%$ with melting point of 145 . The bromo substituen group bound to C-6 are correlated with electron densities and with effects of electrophilic agents. In the other hand, it was assumed to be due to the relatively smaller steric hindrance at C-6 position compared with C-2 and C-5. Pure product can be continued into the synthesis of chalcone.
Synthesis of dimethoxychalcone

The compound of (E)-2'-hydroxy-2-bromo-4,5dimethoxychalcone has been synthesized from 2-bromo-4,5-dimethoxybenzaldehyde and 2hydroxyacetophenone by Claisen-Schmidt condensation. The synthesis was assisted with reflux under an alkaline condition with $40 \%$ $\mathrm{NaOH}$. The synthetic scheme of 2'-hydroxy-2bromo-4,5-dimethoxychalcone was presented in Figure 3.<smiles>COc1cc(Br)c(/C=C/C(=O)c2ccccc2O)cc1OC</smiles>

Figure 3. Synthesis of (E)-2'-hydroxy-2-bromo-4,5-dimethoxychalcone<smiles>COc1cc(Br)c(/C=C/C(=O)c2ccccc2O)cc1OC</smiles>

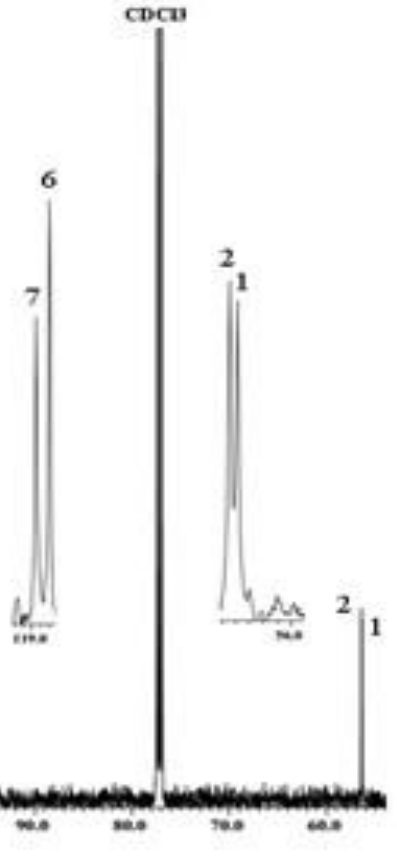

Figure 4. The ${ }^{13}$ CNMR spectra of (E)-2'-hydroxy-2-bromo-4,5-dimethoxychalcone 
The IR spectra showed bands at $3441 \mathrm{~cm}^{-1}$ due to $-\mathrm{OH}$ stretching and the carbonyl group also shifted from $1635 \mathrm{~cm}^{-1}$, which is characteristic peak for conjugated carbonyl vibration. The compound also showed dissapearing peak at $2777 \mathrm{~cm}^{-1}$ (aldehyde) and new peak appeared at $972 \mathrm{~cm}^{-1}$ as trans-bend in FTIR. The mass spectrum of (E)-2'-hydroxy-2bromo-4,5-dimethoxychalcone were equivalent to their theoritical molecular mass at $\mathrm{m} / \mathrm{z} 362$ and 364 for $\mathrm{M}^{+}$, respectively. For ${ }^{1} \mathrm{HNMR}$ spectra showed that formation of trans alkene was also clarified by ${ }^{1} \mathrm{H}$ NMR with double peaks at 7.45 and $8.41 \mathrm{ppm}$ $(J=15.55 \mathrm{~Hz})$. The ${ }^{13} \mathrm{CNMR}$ spectra showed highly deshielded carbonyl carbon (C-17) at 193.51 ppm while the hydroxylated carbon (C-16) appeared at $163.71 \mathrm{ppm}$. The presence of alkene carbon ( $\alpha$ and $\beta$-carbon) resonating at 118.79 and $142.96 \mathrm{ppm}$. The electron density in the double bond is very strongly attracted by carbonyl through resonance. The delocalization of electrons was reduced from $\beta$ carbon to $\alpha$-carbon and resulted in the $\beta$-carbon resonance being more deshielded than $\alpha$-carbon. The spectra ${ }^{13} \mathrm{CNMR}$ was presented in Figure 4. From this characterization showed that compound 2'hydroxy-2-bromo-4,5-dimethoxychalcone has been synthesized. The product was a yellow solid in $78 \%$ with melting point of $169-170^{\circ} \mathrm{C}$.

In Vitro Test of (E)-2'-Hydroxy-2-bromo-4,5dimethoxychalcone against Breast Cancer (MCF-7) Cell Line

The compound of (E)-2'-hydroxy-2-bromo-4,5dimethoxychalcone was tested as anticancer against MCF-7 cell line. In vitro tested as anticancer agent used by MTT Assay method. The compound showed as active in the inhibition of cell growth if they had $I_{50}$ less than $20 \mu \mathrm{g} / \mathrm{mL}, I C_{50}$ between $20-100 \mu \mathrm{g} / \mathrm{mL}$ has moderate activity, and $\mathrm{IC}_{50}$ more than 100 $\mu \mathrm{g} / \mathrm{mL}$ is not active in the inhibition of cell growth (Tanamatarayat, Chunsakaow, \& Duangrat, 2003). Based on this reference, (E)-2'-hydroxy-2-bromo-4,5dimethoxychalcone had moderated activity in the inhibition of breast cancer (MCF-7) cell lines. The $\mathrm{IC}_{50}$ value of (E)-2'-hydroxy-2-bromo-4,5dimethoxychalcone is about $42.19 \mu \mathrm{g} / \mathrm{mL}$. The result similiar to the research conducted by Ketabforoos et al. (2014) which stated that bromo substituents are more active in the inhibition of breast cancer cell lines.

The degree of selectivity of the compounds can be showed by its selectivity index value (Badisa, DarlingReed, Joseph, Cooperwood, \& Latinwo, 2009). Compound as a potential anticancer drug if the degree of selectivity $>2$. While the selectivity index value $<2$ is considered to give general toxicity in which it also can cause cytotoxicity in normal cells (Masriani, Mustofa, Jumina, Sunari, \& Enawaty, 2014). The selectivity index (SI) is an important factor for developing new chemotherapeutical agents due to the undersirable side effect of typical antineoplastic drugs on the normal by standar cells (Ramalho et al., 2013). This value is used to determine how toxic compounds are synthesized againts cancer cells and normal cells. High selectivity index value of a compound gives a selective toxicity towards cancer cells $\left(\mathrm{SI}=\mathrm{IC}_{50}\right.$ for normal cells $/ \mathrm{IC} \mathrm{C}_{50}$ for cancer cells) (Demirgan et al., 2016). The compound showed significant selectivity index value about 27.58 with $I_{50}$ value $1164 \mu \mathrm{g} / \mathrm{mL}$ for vero cell line. In our research showed that 2'-hydroxy-2-bromo-4,5dimethoxychalcone had activity in the inhibition of breast cancer (MCF-7) cell line, whereas low cytotoxicity on the vero cell line. The compound of $2^{\prime}$ hydroxy-2-bromo-4,5-dimethoxychalcone could be considered as anticancer agent due to its $\mathrm{IC}_{50}$ and high selectivity index value.

This $I_{50}$ value of (E)-2'-hydroxy-2-bromo-4,5dimethoxychalcone was compared with $I C_{50}$ value of doxorubicin. Docorubicin usually used to treat cancer in cancer patients. Cytotoxity of doxorubicin againts breast cancer (MCF-7) cell lines is more active than (E)-2'-hydroxy-2-bromo-4,5-dimethoxychalcone with $\mathrm{IC}_{50} 10.61 \mu \mathrm{g} / \mathrm{mL}$. Doxocubicin as standard drug had better anticancer activity than (E)-2'-hydroxy-2bromo-4,5 dimethoxychalcone.

\section{CONCLUSIONS}

In this study, chalcone compounds was successfully synthesized from 2-bromo-4,5dimethoxybenzaldehyde and 2-hydroxyacetophenone with $78 \%$ yield, respectively. The compound of $(E)$ 2'-hydroxy-2-bromo-4,5-dimethoxychalcone has a moderate activity againts breast cancer (MCF-7) cell line with $\mathrm{IC}_{50} 42.19 \mu \mathrm{g} / \mathrm{ml}$. The compound had $\mathrm{IC}_{50}$ value about $1164 \mu \mathrm{g} / \mathrm{mL}$ for vero cell line with selectivity index (SI) value of compound about 27.58. This $I C_{50}$ value of compound compared with $I C_{50}$ of doxorubicin, showed that doxorubicin has better $\mathrm{IC}_{50}$ than chalcone derivative. However, the compound can recommend as candidate for anticancer againts breast cancer (MCF-7) cell lines. For the next research, in vivo test of (E)- 2'-hydroxy-2-bromo-4,5dimethoxychalcone can be carried out.

\section{REFERENCES}

Agrawal, A. (2011). Pharmacological activities of flavonoids: a review. International Journal of Pharmaceutical Sciences and Nanotechnology, 4, 1394-1398.

Badisa, R.B., Darling-Reed, S.F., Joseph, P., Cooperwood, J.S., \& Latinwo, L.M. (2009). Selective cytotoxic activities of two novel synthetic drugs on human breast carcinoma MCF-7 cells. Anticancer Research, 29, 29932996.

Bonakdar, A.P.S., Vafeei, F., Farokhpour, M., Hossein, M., Esfahani, N., Massah, A.R. (2017). Synthesis and anticancer activity assay 
of novel chalcone-sulfonamide derivatives. Iranian Journal of Pharmaceutical Research, 16(2), 565-568.

Demirgan, R., Karagoz, A., Pekmez, M., Onay-ucar, E., Artun, F.T., Gurer C., \& Mat, A. (2016). In vitro anticancer activity and cytitixicity of some papever alkaloids on cancer and normal cell lines. African Journal of Traditional, Complementary and Alternative Medicines, 13(3), 22-26.

Hsieh, H.K., Lee, T.H., Wang, J.P., Wang, J.J., \& Lin, C.N. (1998). Synthesis and antiinflammatory effect of chalcones and related compounds. Pharmaceutical Research, 15(1), 39-46.

Kameshwaean, S., Sresh, V., Arunachalam, G., Kanthal, S., \& Mohanra, M. (2012). In vitro and in vivo anticanceractivity of methanolic extract of tecoma stans flowers. International Research Journal of Pharmacy, 3, 246-251.

Kementerian Kesehatan RI. Situasi Penyakit Kanker. 2015. Available via http://www.depkes.go.id/download.php?file= download/\%20pusdatin/buletin/buletinkanker.pdf (Accessed May 2019).

Ketabforoosh, S. H. M. E., Kheirollahi, A., Safavi, M., \& Esmati, N. (2014). Synthesis and anti-cancer activity evaluation of new dimethoxylated chalcone and flavanone analogs. Archiv der Pharmazie Chemistry in Life Sciences, 347, 853-860.

Masriani, M., Mustofa, M., Jumina, J., Sunarti, S., \& Enawaty, E. (2014). Cytotoxic and proapoptotic activities of crude alkaloid from root of sengkubak (Pynarrhena cauliflora (miers) diels) in human breast cancer $+47 d$ cell line. Scholars Academic Journal of Biosciences, 2(5), 336-340.

Mellado-Garcia, M., Reyna, M., WeinsteinOppenheimer, C., Cuellar, M., \& Aguilar, L.F. (2018). Preliminary evaluation of cytotoxicity for small chalcones on breast and colorectal cancer cell lines: synthesis and structureactivity relationship. Journal of Pharmacology and Therapeutics Forecast, 1(1): 1003.

Rajak, H., Deshmukh, R., Veerasamy, R., Sharma, A.K., Mishra, P., \& Kharya, M.D. (2010). Novel semicarbazones based 25-disubstituted-134oxadiazoles: One more step towards establishing four binding site pharmacophoric model hypothesis for anticonvulsant activity. Bioorganic \& Medicinal Chemistry Letters, 20, 4168-4172.

Ramalho, S.D., Bernades, A., Demetrius, G., NodaPerez, C., Vieira, P.C., dos Santos, C.Y., da Silvab, J.A., de Moraesd, M.O., \& Mousinhod, K.C. (2013). Synthetic chalcone derivatives as inhibitors of cathepsins $k$ and $b$ and their cytotoxic evaluation. Chemistry \& Biodiversity, 10, 1999-2006.
Ranjit, P.M., Rahaman, S.A., Kumar, K.P., Prasad, Y.R., Santhipriya, T., Manikanta, G.C.V.S., \& Sudeepthi, N.R.L. (2013). Synthesis, screening and in vitro anticancer activity of piperazine nucleus containing novel chalcones on different cell lines. International Journal of ChemTech Research, 5(1), 289-293.

Rao, Y. K., Fang, S., \& Tzeng, Y. (2004). Differential effects of synthesized 2'-oxygenated chalcone derivatives: modulation of human cell cycle phase distribution. Bioorganic \& Medical Chemistry, 12(10), 2679-2686.

Sashidhara, K. V, Kumar, A., Kumar, M., Sarkar, J., \& Sinha, S. (2010). Bioorganic \& medicinal chemistry letters synthesis and in vitro evaluation of novel coumarin-chalcone hybrids as potential anticancer agents. Bioorganic \& Medicinal Chemistry Letters, 20(24), 72057211.

Sivakumar, P.M., Muthu Kumar, T., \& Doble, M. (2009). Antifungal activity, mechanism and QSAR studies on chalcones. Chemical Biology \& Drug Design, 74(1), 68-79.

Smith I.C., Heutcheon A.W., \& Heys S.D. (2000). Current and potential chemotherapeutic agents used for induction chemoterapy in the treatment of breast cancer. Current Pharmaceutical Design, 6, 327-343.

Sofiana, A., Balatif, N., \& Zamri, A. (2014). Sintesis dan uji toksisitas senyawa kalkon (E)-1-(2hidroksifenil)-3(4-metoksifenil)prop-2-en-1-on. Repository Universitas Riau.

Syahri, J., Yuanita, E., Nurohmah, B.A., Armunanto, R., \& Purwono, B. (2017). Chalcone analogue as potent anti-malarial compounds against Plasmodium falciparum: synthesis, biological evaluation, and docking simulation study. Asian Pacific Journal of Tropical Biomedicine, 7(8), 675-679.

Syam, S., Abdelwahab, S. I., Al-mamary, M. A., \& Mohan, S. (2012). Synthesis of chalcones with anticancer activities. Molecules, 17, 6179-6195.

Tanamatarayat, P., Chunsakaow, S., \& Duangrat, C. (2003). Screening of some rubiaceous plants for cytotoxicity activity against cervix carcinoma (KB-3-1) cell line. Journal of Pharmaceutical Sciences, 27(3-4), 167-172.

Yu, Y., Shen, M.Y., Song, Q.Q., \& Xie, J.H. (2018). Biological activities and pharmaceutical applications of polysaccharide from natural resources: A Review. Carbohydrate Polymers, 183, 91-101.

Zaini, M.F., Arshad, S., Thanigaimani, K., Khalib, N.C., Zainuri, D.A., Abdullah, M., \& Razak, I.A. (2019). New halogenated chalcones: synthesis, crystal structure, spectroscopic and theoretical analysis for third-order nonlinear optical properties. Journal Molecules Structure, $1195,606-619$. 